\title{
APLIKASI PERBANKAN DAN PERSOALAN RIBAWI DALAM ISLAM MENUJU APLIKASI PERBANKAN BEBAS RIBAWI
}

\author{
Dhany Hermawan. \\ dhanyhermawan34@gmail.com \\ (Dosen Fakultas Agama Islam, Universitas Muhammadiyah Tangerang)
}

\begin{abstract}
Abstrak
Perbankan adalah sebuah institusi keuangan yang membantu perekonomian masyarakat dan pusat agar hal ini tetap berjalan, dan sejalan dengan perbankan nasional, perbankan keislaman menghadirkan nafas segar untuk keberadaan perbankan pusat nasiona. Bagaimanapun, lingkungan menghadapi lagi isu Riba dan Bungan Bank yang selalu dapat diperdebatkan. Untuk itu, dalam hal ini akan didiskusikan tentang perbedaan antara Bunga dan Riba itu sendiri dalam pandangan Islam, sehingga masyarakat bisa memahami bagaimana sistem perbankan Islam yang ada sekarang, lalu nanti akan didiskusikan dalam perbankan keislaman dan masalah ekonomi dalam masyarakat yang berhubungan dengan perbankan konvensional dan perbankan Islam yang tumbuh dengan cepat dalam lingkungan masyarakat, jadi bisa mengetahui bagaimana sistem perbankan berjalan dalam kesesuaian dengan kondisi dan keberadaan yang optimal dalam pembangunan ekonomi saat ini, keduanya baik dalam hal prinsip - prinsip dan produk - produk perbankan Islam, termasuk bunga, riba dan lingkungan kita.
\end{abstract}

\section{Kata Kunci: Perbankan, Islam, Ribawi}

\section{A. Pendahuluan}

Perbankan adalah suatu lembaga yang melaksanakan tiga fungsi utama yaitu menerima simpanan uang, meminjamkan uang, dan jasa pengiriman uang. Di dalam sejarah perekonomian kaum muslimin. Fungsi-fungsi bank telah dikenal sejak jaman Rasulullah SAW, fungsi-fungsi tersebut adalah menerima titipan harta, meminjamkan uang untuk keperluan konsumsi dan keperluan bisnis, serta melakukan pengiriman uang.

Menukar dalam kegiatan ekonomi atau yang biasa disebut dengan barter. Barter dalam kegiatan ekonomi Islam sudah tergolong sebagai Riba Fadl, yang dilarang dalam agama, sedangkan peranan uang sebagai alat tukar dibenarkan ${ }^{1}$. Oleh karena itu, perlu adanya sikap kehatihatian dalam suatu akad atau transaksi,

\footnotetext{
${ }^{1}$ Mannan, Abdul, 1997; 162
}

terutama yang berkaitan dengan jual beli, karena sistem yang berkaitan dengan unsur riba bisa saja terjadi.

Dalam Islam, uang dipandang sebagai alat tukar, bukan suatu komoditi. Diterimanya peranan uang bertujuan untuk melenyapkan ketidakadilan, ketidakjujuran, dan sistem tukar menukar dalam kegiatan ekonomi atau yang biasa disebut dengan barter. Barter dalam kegiatan ekonomi islam sudah tergolong sebagai Riba Fadl, yang dilarang dalam agama, sedangkan peranan uang sebagai alat tukar dibenarkan (Mannan, Abdul, 1997; 162). Oleh karena itu, perlu adanya sikap kehati-hatian dalam suatu akad atau transaksi, terutama yang berkaitan dengan jual beli, karena sistem yang berkaitan dengan unsur riba bisa saja terjadi.

Ada keyakinan dikalangan umat Islam bahwa bank syariah tidak menjalankan sistem ribawi. Selain karena 
berpedoman pada tata cara syariah Islam, bank syariah juga dianggap tidak memberikan bunga, tapi bagi hasil. Hal ini berbeda dengan bank konvensional pada umumnya. Apalagi diperkuat oleh fatwa MUI yang mengatakan bahwa bunga bank adalah riba, bank syariah mungkin bebas dari sistem bunga, tapi hampir mustahil terbebas dari sistem ribawi. Untuk itu kita perlu memahami dengan benar tentang konsep riba dan keberadaannya dalam sistem perbankan, baik dalam sistem perbankan konvensional maupun perbankan syariah, bagaimana dengan keberadaan Perbankan Syariah itu sendiri, untuk itu kita juga perlu mengetahui Prinsip dan Produk perbankan syariah yang bebas dari unsur riba, serta bagaimana tentang konsep bunga dalam perbankan dan lembaga keuangan lain yang telah dikenal dimasyarakat kita selama ini.

\section{B. Kajian Teoritis}

\section{Ribawi, Bunga, dan Islam}

Riba, menurut pengertian bahasa berarti tambahan (az-ziyadah), berkembang (an-numuw), meningkat (alirtifa'), dan membesar (al-uluw). Diriwayatkan oleh al-Bukhari dengan redaksi dan riwayat lain, muslim dan ahmad, dari hadis ibnu abbas. Mereka semua menambahkan perkataan ibnu abbas. "Aku tidak tahu apakah keterangan itu berasal dari al-Qur'an atau tidak" Dengan kata lain, riba adalah penambahan, pengembangan, peningkatan dan pembesaran atas pinjaman pokok yang diterima oleh pemberi pinjaman dari peminjam sebagai imbalan karena menangguhkan atau berpisah dari sebagian modalnya selama periode waktu tertentu. Imam Taqiyuddin, Abu Bakar al-Husaini mengatakan riba menurut syara' berarti tambahan pada emas, perak, beberapa makanan. $^{2}$

Secara garis besar riba dikelompokkan menjadi dua. Masingmasing adalah riba hutang-piutang dan riba jual-beli. Kelompok pertama terbagi lagi menjadi riba qardh dan riba jahiliyyah. Sedangkan kelompok kedua, riba jual-beli, terbagi menjadi riba fadhl dan riba nasi'ah.

1. Riba Qardh, yaitu suatu manfaat atau tingkat kelebihan tertentu yang disyaratkan terhadap yang berhutang (muqtaridh)

2. Riba Jahiliyyah, yaitu hutang dibayar lebih dari pokoknya, karena si peminjam tidak mampu membayar hutangnya pada waktu yang ditetapkan.

3. Riba Fadhl, yaitu pertukaran antarbarang sejenis dengan kadar atau takaran yang berbeda, sedangkan barang yang dipertukarkan itu termasuk dalam jenis barang ribawi.

4. Riba Nasi'ah, yaitu penangguhan penyerahan atau penerimaan jenis barang ribawi yang

dipertukarkan dengan jenis barang ribawi lainnya. Riba dalam nasi'ah muncul karena adanya perbedaan, perubahan, atau tambahan antara yang diserahkan saat ini dengan yang diserahkan kemudian.

Mengenai pembagian dan jenis-jenis riba, berkata Ibnu Hajar al Haitsami: "Bahwa riba itu terdiri dari tiga jenis, yaitu riba-Fadl, riba al-Yaad, dan riba anNasiah. Al mutawally menambahkan jenis keempat yaitu riba al-Qard. Beliau juga menyatakan bahwa semua jenis ini diharamkan secara ijma' berdasarkan nash al Qur'an dan hadits Nabi."

Al-Qur'an dan Sunnah, dua sumber pokok hukum islam melarang keras adanya

${ }^{2}$ Lihat al-Imam Taqiyuddin Abu Bakar alHusaini (1997), Khifayatul Akhyar, Bina Ilmu Surabaya, h.17 
bunga karena kezalimannya, akan tetapi ada yang berpendapat bahwa bunga yang dibayarkan pada saat investasi dalam kegiatan produksi tidak bertentangan dengan hukum Al-Qur'an karena hukum tersebut hanya mengacu kepadaRiba, yaitu pinjaman yang bukan untuk produksi dimasa pra Islam. Pada masa pra Islam, orang tidak mengenal pinjaman produksi dan pengaruhnya pada perkembangan ekonomi. Dalam hal ini mereka yang mengajukan teori bunag tampaknya mengabaikan Al-Qur'an yang merupakan pedoman hidup bagi manusia.

Menyebut Riba dengan nama bunga tidak akan mengubah sifatnya, karena bunga adalah suatu tambahan modal yang dipinjam, karena itu hal tersebut tetaplah Riba. Dalam ekonomi kapitalis, bunga adalah pusat berputarnya sistem perbankan, berdasarkan prinsip dari perbankan konvensional, tanpa bunga sistem perekonomian akan lumpuh. Sedangkan islam mempunyai kekuatan yang sangat dinamis dalam menjalankan sistem perbankan dan lembaga keuangan lain tanpa harus menjalankan sistem bunga.. karena suku bunga yang berlaku dalam perbankan konvensional tidak ada hubungan dengan pengaruh volume menabung. Evolusi konsep riba ke bunga tidak terlepas dari perkembangan lembaga keuangan. Lembaga keuangan timbul karena kebutuhan modal untuk membiayai industri dan perdagangan, modalnya berasal dari kaum pedagang (shahibul maal). Kecenderungan masyarakat menggunakan sistem bunga (interest ataupun unsury) lebih bertujuan untuk mengoptimalkan pemenuhan kepentingan pribadi, sehingga kurang mempertimbangkan dampak sosial yang ditimbulkannya (IBI, (2001:.37). Berbeda dengan sistem bagi hasil (profit-sharing), sistem ini berorientasi pada pemenuhan kemaslahatan hidup umat manusia.

\section{Pembahasan}

\section{Perbankan Syariah dan Masalah Ekonomi}

Pada umumnya yang dimaksud dengan bank syariah adalah lembaga keuangan yang usaha pokoknya memberikan kredit dan jasa-jasa lain dalam lalu lintas pembayaran serta peredaran uang yang beroperasi disesuaikan dengan prinsip-prinsip syariah. Dalam hal ini kegiatan dan usaha bank akan selalu berkaitan dengan komoditas, yang kegiatan usahanya antara lain:

a. Pemindahan uang

b. Menerima dan membayar kembali uang dalam rekening Koran

c. Mendiskonto surat wesel, surat order maupun surat berharga lainnya,

d. Membeli dan menjual surat-surat berharga

e. Memberi kredit, dan

f. Memberi pinjaman kredit

Perbankan syariah dapat diterima oleh semua masyarakat keuangan internasional, bukan hanya yang beragama Islam, dan terus tumbuh dengan signifikan dari tahun ke tahun. Hal ini disebabkan nilai-nilai dalam operasional bank syariah terus berorientasi kepada etika bisnis yang sehat dan juga menawarkan jasa-jasa yang jauh lebih banyak daripada perbankan konvensional. Perbankan syariah dapat menawarkan jasa-jasa lebih dari yang ditawarkan oleh investment banking, karena jasa-jasa bank syariah merupakan suatu kombinasi yang dapat diberikan oleh commercial bank, finance company, dan merchant bank.

Perbankan syariah berlaku untuk semua orang atau Universal. Syariah itu sendiri hanyalah sebuah prinsip atau sistem yang sesuai dengan aturan atau ajaran Islam. Siapa saja dapat memanfaatkan jasa keuangan bank syariah. Ketika krisis moneter melanda Indonesia sistem syariah telah memberikan manfaat bagi banyak kalangan, pada saat krisis yang terjadi pada 
tahun 1997, suku bunga pinjaman melambung tinggi hingga puluhan persen. Akibatnya, banyak dari kalangan usaha yang tidak mampu membayar. Akan tetapi, fenomena ini tidak berlaku bagi pelaku usaha yang menggunakan dana dari bank syariah. Para pengusaha tersebut tidak perlu membayar bunga sampai puluhan persen, mereka cukup berbagi hasil dengan bank syariah. Penentuan persentasi bagi hasil dilakukan di awal pengambilan pinjaman.

Hal yang menjadikan suku bunga pinjaman saat itu melambung yang diterapkan oleh perbankan koknvensional karena menjadikan uang sebagai komoditas, sehingga keberadaan uang saat ini lebih banyak diperdagangkan daripada digunakan sebagai alat tukar dalam perdagangan. Lembaga perbankan konvensional juga menjadikan uang sebagai komoditas dalam proses pemberian kredit. Instrumen yang digunakan adalah bunga (interest). Uang yang memakai instrumen bunga telah menjadi lahan spekulasi empuk bagi banyak orang di muka bumi ini. Kesalahan konsepsi itu berakibat fatal terhadap krisis hebat dalam perekonomian sepanjang sejarah, khususnya sejak awal abad 20 sampai sekarang. Ekonomi berbagai negara di belahan bumi ini tidak pernah lepas dari terpaan krisis dan ancaman krisis berikutnya pasti akan terjadi lagi. Seperti yang telah dijelaskan diawal, bahwa dalam menjalankan sistem perbankan syariah, terutama dalam peneglolaan uang, motif yang digunakan dalam permintaan akan uang-dalam Islam-adalah untuk memenuhi kebutuhan transaksi (money demand for transaction). Dalam konsep Islam, tidak dikenal money demand for speculation, karena spekulasi tidak diperkenankan. Lain halnya dengan sistem konvensional yang tentunya membuka peluang lebar-lebar dengan kebolehan dalam memberikan bunga atas harta. Islam malah menjadikan uang (harta) sebagai objek zakat, uang adalah milik masyarakat sehingga menimbun uang dibawah bantal atau dibiarkan tidak produktif dilarang, karena hal itu mengurangi jumlah uang yang beredar dimasyarakat.

Pada perbankan konvensional, sistem operasi yang diterapkan telah ditetapkan atas dasar kemampuan menghimpun dana masyarakat melalui pelayanan dan sistem bunga yang menarik. Suatu tingkat bunga simpanan akan dikatakan menarik apabila:

1. Lebih tinggi dari tingkat inflasi, karena pada tingkat bunga yang lebih rendah, dana yang disimpan nilainya akan habis dikikis oleh inflasi.

2. Lebih tinggi dari tingkat bunga riil diluar negeri karena pada tingkat bunga yang lebih

rendah dengan dianutnya sistem devisa bebas, dana-dana besar akan lebih menguntungkan untuk diinvestasikan di luar negeri.

3. Lebih bersaing di dalam negeri, karena penyimpan dana akan lebih memilih bank yang

paling tinggi menwarkan tingkat bunga simpanannya dan memberikan berbagai macam bonus dan hadiah. Kemudian pada sisi penyaluran dana tingkat bunga simpanan ditambah dengan persentase tertentu untuk spread yang terdiri dari: biaya operasional, cadangan kredit macet, cadangan kredit, dan profit margin yang dibebankan kepada peminjam dana. Artinya peminjam danalah yang sebenarnya membayar bunga simpanan dan spread bagi bank tersebut.

Berikut dapat dijelaskan dalam tabel, perbedaan antara bunga dan bagi hasil

(Syafi'i Antonio, 2004; 61), yaitu:

\begin{tabular}{|l|l|l|}
\hline \multicolumn{2}{|c|}{ Bunga } & \multicolumn{2}{|c|}{ Bagi Hasil } \\
\hline a & $\begin{array}{l}\text { Penentuan bunga a } \\
\text { dibuat pada waktu } \\
\text { akad dengan } \\
\text { asumsi harus selalu } \\
\text { untung }\end{array}$ & $\begin{array}{l}\text { Penentuan besarnya } \\
\text { rasio/nisbah bagi hasil } \\
\text { dibuat pada waktu akad } \\
\text { dengan berpedoman } \\
\text { pada kemungkinan } \\
\text { untung rugi. }\end{array}$ \\
\hline
\end{tabular}




\begin{tabular}{|c|c|c|c|}
\hline b & $\begin{array}{ll}\text { Besarnya } & \\
\text { persentase } & \\
\text { berdasarkan } & \text { pada } \\
\text { jumlah } & \text { uang } \\
\text { (modal) } & \text { yang } \\
\text { dipinjamkan } & \end{array}$ & b & $\begin{array}{l}\text { Besarnya rasio bagi } \\
\text { hasil berdasarkan pada } \\
\text { jumlah keuntungan } \\
\text { yang diperoleh }\end{array}$ \\
\hline $\mathrm{c}$ & $\begin{array}{l}\text { Pembayaran bunga } \\
\text { tetap seperti yang } \\
\text { dijanjikan tanpa } \\
\text { pertimbangan } \\
\text { apakah proyek } \\
\text { yang dijalankan } \\
\text { oleh pihak nasabah } \\
\text { untung atau rugi }\end{array}$ & $\mathrm{c}$ & 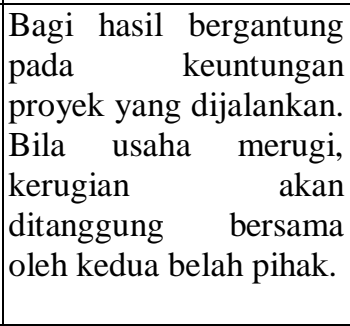 \\
\hline d & $\begin{array}{l}\text { Jumlah } \\
\text { pembayaran bunga } \\
\text { tidak meningkat } \\
\text { sekalipun jumlah } \\
\text { keuntungan } \\
\text { berlipat atau } \\
\text { keadaan ekonomi } \\
\text { sedang } \\
\text { "Booming". }\end{array}$ & $\mathrm{d}$ & \begin{tabular}{|lr} 
Jumlah pembagian laba \\
meningkat & sesuai \\
dengan rangkatan \\
jumlah pendapatan.
\end{tabular} \\
\hline e & $\begin{array}{l}\text { Eksistansi } r \text { bunga } \\
\text { diragukan oleh } \\
\text { agama, teruatama } \\
\text { agama islam }\end{array}$ & $\mathrm{e}$ & $\begin{array}{l}\text { Tidak ada yang } \\
\text { meragukan keabsahan } \\
\text { bagi hasil. }\end{array}$ \\
\hline
\end{tabular}

Dalam hal tersebut jelas terlihat dalam sistem keuangan yang dijalankan antara perbankan konvensional dan perbankan syariah, dan secara makro, praktek menggunakan sistem bunga yang juga merupakan bagian dari sistem ekonomi, tentu saja memberikan situasi yang dilematis dan kontradiktif bagi pemerintah. Dilematis, pemerintah dihadapkan pada dua pilihan yang samasama diperlukan, yaitu pertumbuhan ekonomi yang tinggi, atau kestabilan ekonomi. Untuk mengacu pada kegiatan ekonomi, biasanya diperlukan kebijakan uang longgar dengan menambah pasokan kredit perbankan melonggarkan pasokan investasi asing dan pinjaman luar negeri tetapi dapat mengakibatkan bertambahnya jumlah uang yang beredar sehingga dapat menaikkan tingkat inflasi. Untuk mengendalikan tingkat inflasi tersebut, biasanya diperlukan kebijakan uang ketat untuk mengurangi pasokan kredit perbankan akan tetapi dapat mengakibatkan lesunya kegiatan ekonomi. Selanjutnya kontradiktif, karena pada upaya pemerintah untuk mengendalikan inflasi dengan kebijakan uang ketat tadi akan ditanggapi oleh perbankan konvensional dengan menikkan tingkat bunga yang mengakibatkan ekonomi biaya tinggi, kelesuan ekonomi, dan dorongan inflasi kembali. Kecenderungan kenaikan harga yang terus menerus (inflasi) sebenarnya bisa disebabkan adanya ketidakseimbangan disektor riil, seperti hambatan produksi karena efisiensi, hambatan impor untuk proteksi produksi, dan lain sebagainya.

Dalam hal ini telah tampak jelas terlihat, disaat perekonomian indonesia saat ini sedang labil, sistem perbankan syariah harus bisa tetap eksis dalam hal mekanisme keuangan syariah untuk mengatasi kerugian yang disatu pihak disebabkan oleh keberadaan sistem keuangan konvensional yang merugikan masyarakat.

\section{Prinsip dan Produk perbankan syariah}

Dalam bank syariah, hubungan antara bank dengan nasabahnya bukan hubungan antara debitur dan kreditur, melainkan hubungan kemitraan (parthnership), antara penyandang dana (shohibul maal), dengan pengelola dana (Mudharib). Oleh karena itu, tingkat laba bank syariah tidak saja berpengaruh terhadap tingkat bagi hasil untuk para pemegang saham tetapi juga berpengaruh terhadap bagi hasil yang dapat diberikan kepada nasabah penyimpan dana.

Secara umum, piranti-piranti yang digunakan bank syariah terdiri atas tiga kategori, yaitu:

1. Produk penyaluran dana (financing)

2. Produk penghimpunan dana (funding)

3. Produk jasa (services) 
Penghimpunan dana di Bank syariah dapat berbentuk giro, tabungan dan deposito. Prinsip operasional syariah yang diterapkan dalam penghimpunan dana masyarakat yaitu berupa:

a) Wadiah, Wadiah yang diterapakan yaitu wadiah yad dhamamah, yang diterapkan pada rekening giro.

b) Mudharobah, dalam mengimplikasikan prinsip mudharobah, penyimpan atau deposan

Bertindak sebagai shahibul maal (pemilik modal) dan bank sebagai mudharib (pengelola). Berdasarkan kewenangan yang diberikan oleh pihak penyimpan dana, prinsip Mudharobah terbagi menjadi dua yaitu Mudharobah Mutlaqah dan Mudharobah Muqayyadah. Jenis pembiayaan yang paling sering dipakai oleh kaum Muslim dalam perjalanan sejarah mereka adalah mudharabah dan musyarakah (partnership).

Mudharabah adalah suatu bentuk perkongsian dengan salah satu pihak bertindak sebagai financier (penyedia dana finansial), sedangkan pihak yang lain menyediakan jasa keusahaan (entrepreneurship). Pada posisi demikian, sang financier bukanlah bertindak sebagai pemberi pinjaman dana (lender atau creditor), melainkan sebagai investor yang akan menyumbangkan dana finansial itu untuk tujuan-tujuan produktif. Sebaliknya, sang pengelola dana akan bertindak sebagai entrepreneur (fund manager) dan bukan sebagai debitor.

Hubungan yang terjalin di antara kedua belah pihak merupakan suatu hubungan kemitraan dan kerja sama dan bukan layaknya hubungan yang terjadi dalam transaksi pinjam-meminjam. Keuntungan dari usaha ini akan dibagi dua berdasarkan proporsi yang disepakai oleh kedua belah pihak. Namun, jika terjadi kerugian, sang financier yang akan mendapatkan kerugian, sedangkan pengelola dana akan kehilangan tenaga dan waktunya.

Dalam musyarakah sang financier terlibat langsung terhadap proses kegiatan bisnis. Ia berbeda darimudharabah karena dalam mudharabah sang financier adalah seorang mitra tidur (sleeping partner). Jika terjadi kerugian, kerugian itu akan dihitung proporsional terhadap modal yang telah disetor dalam perkongsian ini. Jika terjadi keuntungan, maka akan dibagikan berdasarkan proporsi yang telah disepakati di depan. Liabilitas sangfinancier akan terbatas hanya pada jumlah pembiayaan yang diberikan dalam usaha ini.

Sekalipun Islam melarang transaksi berbasis bunga dan menggalakkan penyertaan modal sendiri (equity financing), Islam tidak mengharamkan kredit secara umum. Islam membolehkan penyaluran kredit yang langsung berhubungan dengan pembelian barang dan jasa. Ini dapat kita lihat dalam jual beli, murabahah, salam, dan istihna'. Murabahah merupakan suatu perjanjian penjualan dengan penjual membelikan suatu barang yang dibutuhkan oleh pembeli kemudian menjualnya kepada pembeli dengan suatu margin keuntungan yang disepakati. Pembayaran dapat dilakukan lewat cicilan maupun lump sum.

Dalam jual beli salam, pembelian dengan penyetoran seluruh harga dilakukan di depan, sedangkan barang yang dipesan akan diantarkan di masa yang akan datang. Sementara istishna' adalah suatu perjanjian penjualan ketika seorang kontraktor menyepakati untuk memproduksi atau membangun dan mengantarkan suatu barang tertentu yang dipesan dengan suatu harga yang telah disepakati dengan pihak pemesan. Pembayaran dapat diberikan lewat cicilan atau sesuai dengan kemajuan pembuatan barang yang dipesan.

Pada prinsip Mudharabah yang dilakukan oleh perbankan syariah sama 
persis dengan definisi mudharabah yang dikenal dalam kitab-kitab fiqih. Bank bertindak sebagai pelaksana usaha (mudharib) dan nasabah bank bertindak sebagai pemilik dana. Dana tersebut digunakan bank untuk melakukan murabahah atau ijarah seperti yang telah dijelaskan terdahulu. Dapat pula dana tersebut digunakan bank untuk melakukan mudharabah kedua. Hasil usaha ini akan dibagi hasilkan berdasarkan nisbah yang disepakati. Rukunmudharabah terpenuhi sempurna (ada mudharib - ada pemilik dana, ada usaha yang akan dibagi hasilkan, ada nisbah, ada ijab-kabul), dengan demikian dapat dikatakan akad mudharabah ini sah.

Di samping itu ada juga modal yang lain seperti ijarah (leasing). Kesemua modal ini dimaksudkan untuk memenuhi tuntutan kegiatan bisnis pada masa itu dan dapat juga dipergunakan secara luas dalam kegiatan bisnis modern. Banyak sarjana dan peneliti non-Muslim yang membuktikan bahwa perdagangan internasional yang dilakukan oleh kaum Muslim pada masa kejayaan mereka umumnya dimotori oleh pembiayaan mudharabah dan musyarakah. Hampir di seluruh bidang industri telah memakai moda ini termasuk dalam pembiayaan pertanian, kerajinan, industri olahan dan perdagangan luar negeri baik antar-Muslim maupun dengan mereka yang non-Muslim seperti Yahudi dan Nasrani.

Begitu luasnya penggunaan modal pembiayaan ini dalam memobilisasi modal dan mudahnya akses bagi dunia usaha maka terjadilah pertumbuhan ekonomi yang begitu cepat dan besar dalam perekonomian dunia Islam. Di samping itu pola ini telah mendorong lebih jauh perdagangan internasional mulai dari Maroko dan Spanyol di Barat sampai ke India, Cina, dan Asia Tengah di Timur. Ini tidak hanya direkam oleh data sejarah yang dapat ditemukan di perpustakaan- perpustakaan, tetapi juga oleh kenyataan ditemukannya mata uang Islam di berbagai belahan dunia seperti di Rusia, Finlandia, Swedia, Norwegia, dan Inggris.

Tentu saja dalam menjalankan operasionalnya, bank syariah harus berpedoman kepada fatwa Dewan Pengawas Syariah, sedangkan pada bank konvensioanal tidak terdapat dewan sejenis; Hubungan antara investor (penyimpan dana) dengan pengguna dana dan banksebagai intermediary berdasarkan kemitraan, bukan hubungan debiturkreditur; Bisnis Bank Syariah bukan hanya berdasarkan profit oriented tetapi falah oriented, yakni kesejahteraan di dunia dan kemakmuran di akhirat; Konsep yang digunakan dalam transaksi Bank Syariah berdasarkan prinsip bagi hasil, jual beli, dan pengambilan fee/jasa; Bank Syariah hanya melakukan investasi yang halal dan tidak menimbulkan kemudharatan atau bencana bagi umat manusia.

\section{Bunga, Riba dan Masyarakat}

Sudah banyak terobosan yang telah dilakukan oleh pengembang konsep ekonomi Islam yang semuanya bermuara untuk memajukan dunia perbankan syariah di Indonesia. Mulai dari MUI yang telah mengeluarkan fatwa tentang bunga bank haram. Kemudian disusul dengan beberapa kebijakan yang dikeluarkan BI, melalui Direktorat Perbankan Syariahnya, diantaranya telah mengeluarkan kebijakan office chanelling bagi bank konvensional yang telah membuka Unit Usaha syariah (UUS) untuk memberikan pelayanan transaksi syariah bagi masyarakat luas.

Kondisi di atas merupakan bukti riil dukungan terhadap pengembangan industri perbankan syariah di Indonesia. Tetapi, hasilnya masih dirasakan kurang memuaskan. Sampai saat ini, tercatat market share industri perbankan syariah Indonesia masih $1,5 \%$ dari total market share industri perbankan nasional. Artinya, 
98,5\% market share industri perbankan nasional masih dikuasai oleh dunia perbankan konvensional. Satu hal yang ironis. Pertama, mayoritas penduduk Indonesia beragama Islam merupakan potential market yang dapat mendukung pengembangan perbankan syariah di Indonesia. Hal ini dapat difahami masih banyak umat Islam yang belum tergerak hatinya untuk bergabung bersama merapatkan barisan dalam pengembangan ekonomi Islam, khususnya melakukan transaksi pada perbankan syariah. Kedua, keberadaan industri perbankan syariah relatif sudah berjalan hampir 15 tahun lebih. Berarti, eksistensi bank syariah sudah tidak lagi seperti anak kecil yang geraknya tidak lincah, tetapi sudah menjadi pemuda yang diharapkan dapat bergerak lebih lincah dan responsif terhadap kondisi perkembangan zaman.

Pendapat bahwa bunga sebagai kompensasi dari terjadinya penurunan nilai uang dimasa datang (inflasi) merupakan argumen umum yang sering digunakan. Oleh karena itu, bunga tidak hanya sebagai harga dari uang saja melainkan sebagai imbalan risiko inflasi bagi pemilik uang. Pendapat ini sebenarnya sangat lemah lemah, karena telah kita ketahui bersama dalam perekonomian seperti sekarang bunga merupakan salah satu penyebab terjadinya inflasi sehingga sering digunakan sebagai intrumen untuk mengendalikan inflasi. Apakah relevan mengatasi akibat dengan menyuburkan penyebabnya. Dari hal ini maka jelaslah bahwa bunga merupakan penyakit ekonomi sehingga sudah seharusnya dihindari.

Di sisi lain, tingkat bunga akan dapat menyebabkan pola konsumsi masyarakat berubah, yaitu pada saat bunga berada pada tingkat rendah, biasanya tingkat konsumsi akan naik yang disebabkan oleh bunga kredit rendah baik konsumsi individual maupun konsumsi untuk investasi, naiknya tingkat konsumsi akan menaikkan harga barang atau akan terjadi peningkatan inflasi. Perkembangan lembaga keuangan syariah dengan berbagai instrumen yang ada menimbulkan optimisme akan perubahan sikap mayarakat terhadap keadaan riba. Tetapi masih terdapat beberapa alasan yang menjadikan bunga kurang diterima sebagai riba. Alasan tersebut diantaranya, karena berhubungan erat dengan masalah emosi keagamaan masyarakat yang melibatkan "keyakinan" masyarakat terhadap kedudukan riba sebagai bunga. Selanjutnya adanya kritis terhadap lembaga keuangan syariah, sebagian masyarakat yang menolak bunga sebagai riba, dan masyarakat muslim lebih familiar berkepentingan terhadap lembaga keuangan konvensional. Hal inilah yang menjadi tugas perbankan syariah kedepannnya untuk lebih mengenalkan perbankan yang berbasis islami dan bebas riba yang perlu diterapkan di masyarakat secara luas.

Dalam hal ini masyarakat tentu saja ingin mendapatkan kenyaman dalam pengelolaan keuangan mereka, terutama mengenai kepercayaan akan keberadaan sistem perbankan islam. Dengan demikian, keberadaan perbankan Islam menjadi sangat fundamental sekali untuk terus melakukan pengembangan dan meningkatkan kinerja perbankan syariah. Dengan tujuan sistem keuangan dan perbankan Islam untuk mencapai: kemakmuran ekonomi yang meluas dengan tingkat kerja yang penuh dan tingkat pertumbuhan ekonomi yang optimum (economic well-being with full employment and optimum rate of economic growth); dan keadilan sosial ekonomi dan distribusi pendapatan dan kekayaan yang merata (socio-economic justice and equitable distribution of income and wealth). 


\section{Kesimpulan}

Riba bukan hanya merupakan persoalan masyarakat Islam, tetapi berbagai kalangan di luar Islam pun memandang serius per-soalan ini. Karenanya, kajian terhadap masalah riba dapat dirunut mundur hingga lebih dari 2.000 tahun silam. Masalah riba telah menjadi bahan bahasan kalangan Yahudi, Yunani, demikian juga Romawi. Kalangan Kristen dari masa ke masa juga mempunyai pandangan tersendiri mengenai riba. Maka, sepantasnya bila kajian tentang riba pun melihat perspektif dari kalangan non-Muslim tersebut. Perdebatan masalah haramnya riba selama ini masih banyak pada tataran normatif dan dalil naqli saja, belum banyak pada kajian ekonomi secara teoritis dan empirik (dalil aqli), apalagi yang berhubungan erat dengan sistem keuangan atau perbankan. Untuk itu perlu adanya kajian lebih lanjut tentang haramnya bunga (riba) dengan pendekatan ekonomi secara teoritik dan empirik. Dengan membentuk suatu konsep yang difokuskan pada paradigama hubungan sistem bunga, investasi dan pertumbuhan ekonomi, dan paradigama hubungan sistem bagi hasil, investasi dan pertumbuhan ekonomi. Sehingga hasil kajian nantinya diharapkan dapat menjawab kontroversi riba, sehingga masyarakat yang memilih sistem ekonomi islam tidak hanya didasari oleh doktrin normatif agama saja melainkan juga didasari oleh cost and benefit secara ekonomis.

\section{DAFTAR PUSTAKA}

Abdul Aziz Setiawan, Riba dalam Transaksi Bisnis, (25 Mei 2008)

Antonio, Syafi'i, 2004, Bank Syariah, dari Teori dan Prkatek, Gema Insani, Jakarta
Antonio, Syafii, Riba dalam Perspektif Agama dan Sejarah, (12 Februari 2008)

http://agustianto.niriah.com/2008/04/11/ko nsep-uang-dalam-ekonomiislam/ (18 April 08)

Karim, Adiwarman, A, 2007, Bank Islam, Analisis Fiqih dan Keuangan, PT. Raja Grafindo Persada, Jakarta.

Mannan. Abdul, 1997, Teori Dan Praktek Ekonomi Islam, PT. Dana Bhakti Wakaf, Yogyakarta

Muhammad, 2002, Manajemen Bank Syariah, UPP AMP YKPN, Yogyakarta

Muhammad, 2000, Sistem dan Prosedur Operasional Bank Syariah, UII Press, Yogyakarta

Qardhawi, Yusuf, 2001, Bunga Bank. Cetakan pertama, Akbar Media Eka Sarana, Jakarta

Roy Davies dan Glyn Davies, 1996, dalam buku "A History of Money from Ancient Time to the Present Day"

Sudarsono, Heri, 2004, Bank dan Lembaga Keuangan Syariah, Deskripsi dan Ilustrasi, edisi 2. Ekonisia, kampus Fakultas Ekonomi UII, Yogyakarta

Sudin Haron, 1997, Islamic Banking: Rules and Regulations, Pelanduk Publications, Petaling Jaya

Sutan Remy Syahdeini, 1999, Perbankan Islam dan Kedudukanya dalam Tata Hukum Perbankan Indonesia, Grafiti, Jakarta

Taqiyuddin, Abu Bakar, al-Husaini, 1997, Khifayatul Akhyar, Bina Ilmu, Surabaya

Tim Indonesia School of Life (ISOL), Prinsip Dasar Produk Perbankan Syariah, dalam, (23 Mei 2008)

Tim redaksi, 1994, Ensiklopedi Hukum Islam, PT. Ikhtiar Baru, Van Hoeve, Jakarta 
